
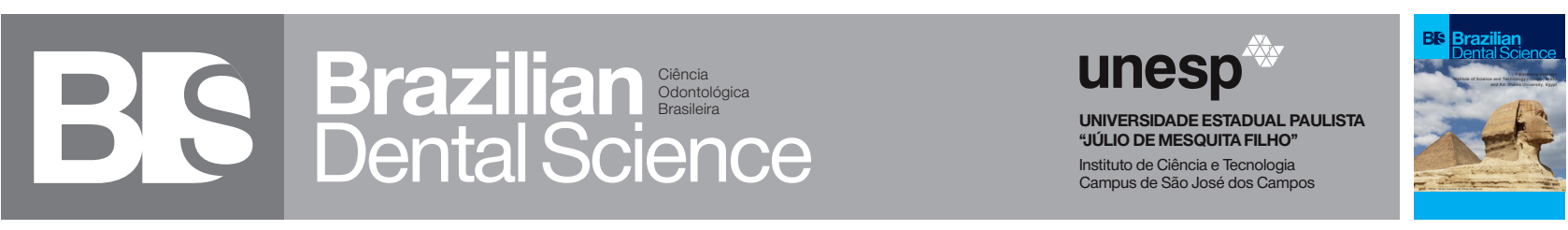

\title{
Application of Bio-Oss in tissue regenerative treatment prior to implant installation: literature review
}

\author{
Aplicação de Bio-Oss em tratamento regenerativo tecidual previamente a instalação de implante: revisão da literatura
}

\begin{abstract}
Alessandra de Carvalho MOREIRA ${ }^{1}$, Jhenifer Rodrigues SILVA ${ }^{1}$, Renata de Paula SAMICO ${ }^{2}$, Gabriela Nogueira de Melo NISHIOKA ${ }^{2}$, Renato Sussumu NISHIOKA ${ }^{2}$

1 - São Paulo State University (Unesp) - Institute of Science and Technology - São José dos Campos - SP - Brazil.

2 - São Paulo State University (Unesp) - Institute of Science and Technology, São José dos Campos - São José dos Campos - Department of Dental Materials and Prosthodontics - SP - Brazil.
\end{abstract}

\section{ABSTRACT}

Objetivo: Bio-Oss is a xenogene bone graft in which all organic components are removed while retaining their natural mineral architecture. Therefore, the aim of this study was to evaluate, through a literature review, the benefits of using Bio-Oss for tissue regenerative treatment prior to implant placement. Material and methods: a search was performed in Pubmed (Medline) in order to identify articles published in English between January 1, 2000 and June 31, 2018, where the Bio-Oss graft was used prior to implantation of implants in humans. A total of 40 studies were selected for detailed analysis. From this analysis, 18 articles were identified for inclusion in this review. Results: the articles analyzed in the review showed several beneficial effects of this xenograft, such as: positive osteoconductive properties, recovery of bone heights at sites with severe atrophies, slow xenograft reabsorption suggesting long term stability, survival rates and success of implants placed in grafted sites ranging from 91 to 100\% in several studies. Conclusion: the use of bio-oss as a bone substitute is a viable alternative in the placement before dental implants, being used in clinical practice and with proved efficacy in several studies, due to its similarity with the bone and its high level of osteoconductivity.

\section{KEYWORDS}

Bio-Oss; Bone Graft; Implants.

\section{RESUMO}

Objetivo: o Bio-Oss é um substituído ósseo xenógeno em que são removidos todos os componentes orgânicos, mantendo sua arquitetura natural. Assim, este trabalho teve como foco avaliar através de uma revisão de literatura os benefícios do uso do Bio-Oss para tratamento regenerativo tecidual previamente a instalação de implantes. Material e métodos: realizou-se uma busca no Pubmed (Medline) com intuito de se identificar artigos publicados em inglês entre 1 de janeiro de 2000 e 31 de junho de 2018, em que se utilizava o enxerto Bio-Oss previamente a instalação de implantes em humanos. Foram selecionados 40 estudos completos para uma análise detalhada. A partir dessa análise foram identificados 18 artigos para inclusão nessa revisão. Resultados: os artigos analisados na revisão mostraram diversos efeitos benéficos desse xenoenxerto, como: propriedades osteocondutoras positivas, recuperação de alturas ósseas em locais com atrofias graves, reabsorção lenta do xenoenxerto sugerindo estabilidade a longo prazo, taxas de sobrevivência e sucesso de implantes colocados em locais enxertados variando de 91 a 100\% em diversas pesquisas. Conclusão: a utilização do biooss como substituto ósseo é uma alternativa viável na colocação previamente ao implante dentário, sendo utilizado na prática clínica e comprovado em diversos estudos sua eficácia, devido sua similaridade com o osso natural e seu alto grau de osteocondutividade.

\section{PALAVRAS-CHAVE}

Bio-Oss; Enxerto Ósseo; Implantes. 


\section{INTRODUCTION}

$\mathrm{O}$ ne of the dentist's challenges in surgical clinical practice, is to deal with bone reconstruction that comes after trauma, infection, neoplasies or periodontal disease [1]. The use of bone grafts aims to improve bone regeneration after surgical procedures and works as a support to blood clot, reducing the risk of soft tissue breakdown in the bone defects [2].

Bone grafts can be classified as autogenous, harvested from donor site of the patient itself; homologous, when collected in the same species, but different individuals; xenogene, when collected in different species; alloplastic, when formed by a laboratory developed synthetic material $[3,4]$.

The characteristics of an ideal bone graft material are: can be gradually replaced by newly formed bone, have osteoconductive or osteoinductive properties [5], be biocompatible and easy to manage during surgical procedures [6].

Autogenous grafts are considered
"gold standard" due to its osteogenic,
osteoconductive and osteoinductive properties
[7]. Its predictability is the main choosing fator,
concerning that is the only one that offers to
the receiver site, cells with growth factors and
with bone neoformation properties [8]. Their
disadvantages are associated to a higher post
operative morbidity, donor site availability,
unforseen graft resorption, and many times,
the need of extraoral harvesting sites. [9,10].

With the focus on overcome such limitations and in association with high scientific and technological development, the biomaterials have arised as an altertative to the use of autogenous grafts [11].

Bovine biomaterials are used as a bone replacement material and have been studied since the 60's. Bio-Oss (Geistlich) is a xenogene bone graft, which all the organic compounds are removed, maintaining its natural mineral architecture. Its structure is physically and chemically comparable to the mineralized matrix of human bone [12]. Besides, presentes the advantage towards the autogenous bone graft the fact of being slowly reabsorbed, acting as a scaffold to new bone formation during all the regenerative process $[10,13,14]$.

Concerning the researches that have been developed, it was examined that there are previous studies about this theme, being one of the most studied materials owing to its proven osteoconductive properties [13-17]. However, few recent studies were found, being required a new literature review that approaches the advantages of using Bio-Oss (Geistlich) and the case report that assures its efficacy in clinical practice. Therefore, the aim of this study was to evaluate through a litetature review the benefits of Bio-Oss to regenerative tissue treatment previously to implants placement.

\section{MATERIAL AND METHODS}

A search into PubMed (MEDLINE) was made in order to identify scientific articles in english, published between January 1st, 2000 to 31st of june 2018, where the use of Bio-Oss used previouly to implant placement was performed. The search was made using the key-words: Bio-Oss, dental implants, bone grafts, implant, human, bone transplantation.

The initial search resulted in 262 articles. Therefore, after title and abstract critical reading, some studies were excluded because they found to be incompatible to the objective of this study, and 40 articles were selected to a detailed analysis. From this analysis, 18 articles were finally selected to be included in this review, and only randomized controlled trials.

Accordingly, from the 40 initially selected articles, 22 articles were excluded of final analysis. The major causes of exclusion were: articles that consisted in literature reviews, articles where the objective of the research was not Bio-Oss evaluation, articles that used Bio-Oss together with another kind of bone graft, and articles where the implant placement was done simultaneously with BioOss. (figure1) 
INITIAL SEARCH

262 articles

Published between January

1st, 2000 to 31st of june 2018, where the use of Bio-Oss.

\section{DETAILED ANALYSIS}

\section{0 studies}

After title and abstract critical reading.

18 Articles included

Randomized clinical trials that review the benefits of Bio-Oss to regenerative tissue treatment previously to implants placement.

\section{Articles excluded}

Literature reviews, articles where the objective of the research was not Bio-Oss evaluation, articles that used Bio-Oss together with another kind of bone graft, and articles where the implant placement was done simultaneously with Bio-Oss

Figure 1- Search strategy.

\section{RESULTS}

The results of the bibliographic research were presented through the Table 1 bellow that demonstrated the main features of the articles selected in this study. 
Table 1 - Results found in the articles about the benefits of Bio-Oss usage

\begin{tabular}{|c|c|c|c|}
\hline Autor & Objective & Follow-up period & Benefits of Bio-Oss usage \\
\hline $\begin{array}{l}\text { Milani S, Dal Pozzo L, } \\
\text { Rasperini G, Sforza } \\
\text { C, Dellavia C.(2016) } \\
\text { [18] }\end{array}$ & $\begin{array}{l}\text { Investigate, through an imune-histochemical } \\
\text { method, patterns of deproteinized bovine bone } \\
\text { remodelling in humans. }\end{array}$ & Five months. & $\begin{array}{l}\text { - Osteointegration process } \\
\text { - Newly formed bone tissue between graft particles. } \\
\text { - Keeps the activity in bone remodelling process. } \\
\text { - Confirms the bioconductive properties of Bio-0ss }\end{array}$ \\
\hline $\begin{array}{l}\text { Schmitt CM et } \\
\text { al.(2015) } \\
\text { [19] }\end{array}$ & $\begin{array}{l}\text { Investigate the histological patterns and implant } \\
\text { survival rates } 5 \text { years after maxillary sinus grafting } \\
\text { with bovine inorganic bone graft (Bio-0ss) and Bio- } \\
\text { Oss with autogenous bone with 1/1 proportion. }\end{array}$ & $\begin{array}{l}\text { Five years and two } \\
\text { months. }\end{array}$ & $\begin{array}{l}\text { - The isolated use of Bio-0ss avoids donor site mobidity. } \\
\text { - Apropriate to maxilar sinus grafting. } \\
\text { - Confirmed the material's conductivity. } \\
\text { - Suitable for bone preservation and long term sucess. }\end{array}$ \\
\hline $\begin{array}{l}\text { Meloni SM et } \\
\text { al.(2015) } \\
\text { [20] }\end{array}$ & $\begin{array}{l}\text { Test the hypothesis that the placed implants in } \\
\text { maxillary sinus grafted with bovine inorganic bone } \\
\text { graft(Bio-0ss) presented comparable results to those } \\
\text { that were grafted with bovine and autologous graft. }\end{array}$ & Twelve months. & $\begin{array}{l}\text { - Survival rate of } 91 \% \text { to } 100 \% \text { to implants placed in } \\
\text { maxillary sinus grafted with Bio-0ss } \\
\text { - Suitable for maxillary sinus grafting. }\end{array}$ \\
\hline $\begin{array}{l}\text { Lutz R, Berger } \\
\text { FS, Stockmann } \\
\text { P, Neukam FW, } \\
\text { Schlegel KA.(2015) } \\
\text { [21] }\end{array}$ & $\begin{array}{l}\text { Evaluate retrospectively the clinical results after } \\
\text { maxillary sinus grafting with autogenous bone } 0 \mathrm{R} \\
\text { Bio-0ss after a } 5 \text {-year follow-up period. }\end{array}$ & Five years. & $\begin{array}{l}\text { - Resultados clínicos previsíveis a longo prazo. } \\
\text { - Taxas de sobrevivência dos implantes mostraram-se } \\
\text { equivalentes em comparação com enxerto autógeno. }\end{array}$ \\
\hline $\begin{array}{l}\text { Çiftçi NF,Acar } \\
\text { AH.(2015) } \\
\text { [22] }\end{array}$ & $\begin{array}{l}\text { Evalute retrospectively results after } 3 \text {-year follow-up } \\
\text { period, of implants placed in maxillary sinus grafted } \\
\text { with minimal residual bone Heights }(\leq 3 \mathrm{~mm})\end{array}$ & Three years. & $\begin{array}{l}\text { 98,28\% long term sucess rates of implants placedin } \\
\text { maxillarysinus grafted } \\
\text { Suitable to reconstruct maxillary sinus and suport } \\
\text { dental implant. } \\
\text { Bio-Oss particles conects between each other } \\
\text { through bone bridges and are covered by recently } \\
\text { formed bone tissue }\end{array}$ \\
\hline $\begin{array}{l}\text { Pang C, Ding Y, Zhou } \\
\text { H, Qin R, Hou R, } \\
\text { Zhang G, Hu K.(2014) } \\
\text { [23] }\end{array}$ & $\begin{array}{c}\text { Evaluate clinically and radiographically an } \\
\text { alveolar bone crest, preservation technique with } \\
\text { deproteinized bovine bone graft and reabsorbable } \\
\text { collagen membrane, and aftewards, late implant } \\
\text { placement. }\end{array}$ & Twenty months. & $\begin{array}{l}\text { - Reduces alveolar crest reabsorption when placed in } \\
\text { extractions sites. }\end{array}$ \\
\hline $\begin{array}{l}\text { Lange GL, et } \\
\text { al.(2014) } \\
\text { [24] }\end{array}$ & $\begin{array}{c}\text { Compare the gain of mineralized bone between the } \\
\text { allograft of deproteinized bovine bone graft (DBA) and } \\
\text { biphasic calcium phosphate (BCP) to placement of } \\
\text { dental implant }\end{array}$ & Four years. & $\begin{array}{l}\text { - Confirms osteoconductives properties. } \\
\text { - Suitable to recover maxillary bone heightto implant } \\
\text { placement in patients with severe maxillary atrophy }\end{array}$ \\
\hline $\begin{array}{l}\text { Schmitt CM, } \\
\text { Doering H, Schmidt } \\
\text { T, Lutz R, Neukam } \\
\text { FW, Schlegel } \\
\text { KA.(2013) } \\
\text { [25] }\end{array}$ & $\begin{array}{l}\text { Compare clinical and histological features after } \\
\text { maxillary sinus grafting with biphasic calcium } \\
\text { phosphate (BCP, Straumann BoneCeramic), } \\
\text { inorganic bovine bone (ABB,Bio-Oss, Geistlich), } \\
\text { trabeculed mineralized bone graft (MCBA, Zimmer } \\
\text { Puros), or autologous bone(AB) }\end{array}$ & Five months. & $\begin{array}{l}\text { Suitable for maxillary sinus grafting } \\
\text { - Bio-Oss a non-resorbable bone substitute has } \\
\text { osteoconductives properties. } \\
\text { - Intimate contact between substitute and newly } \\
\text { formed bone. }\end{array}$ \\
\hline $\begin{array}{l}\text { Bassil J. et al.(2013) } \\
\text { [26] }\end{array}$ & $\begin{array}{l}\text { Investigate histologically and histomorphometrically } \\
\text { human biopsies when Bio-Oss was used alone in } \\
\text { surgical practice enviroment to maxillary sinus lifting } \\
\text { procedures. }\end{array}$ & Twenty months. & $\begin{array}{l}\text { - Confirms its osteoconductives properties and it is } \\
\text { suitable for bone defects treatments and maxillary } \\
\text { sinus grafting } \\
\text { - Bio-Oss used alone showed a implant sucess rate of } \\
100 \% \text { after } 12 \text { months of loading. } \\
\text { - Behaved as a scaffold through which newbone was } \\
\text { formed. } \\
\text { - Intimate contact between Bio-0ss particles and newly } \\
\text { formed bone without gaps in the interface. } \\
\text { - Confirms its good biocompatibility } \\
\text { - There were no negative effects presented with the use } \\
\text { of Bio-Oss. }\end{array}$ \\
\hline
\end{tabular}




\begin{tabular}{|c|c|c|c|}
\hline Autor & Objective & Follow-up period & Benefits of Bio-0ss usage \\
\hline $\begin{array}{l}\text { Oliveira R, Hage ME, } \\
\text { Carrel JP, Lombardi } \\
\text { T, Bernard JP.(2012) } \\
\text { [27] }\end{array}$ & $\begin{array}{l}\text { Evaluate the long-term survival rate } \\
\text { of wide platform implants placed in } \\
\text { maxillarysinus grafted with deproteinized } \\
\text { bovine bone graft } \\
\text { (Bio-Oss; Geistlich Pharma AG, Wolhusen, } \\
\text { Switzerland). }\end{array}$ & Nine years. & $\begin{array}{l}\text { - Confirms that Bio-Oss is biocompatible and osteoconductive. } \\
\text { - Particles of Bio-Oss remans many years after bone graft } \\
\text { placement. } \\
\text { - The long term maintainance of Bio-Oss, as long as provides } \\
\text { suport and density, doesn't interfere in osteointegration process. } \\
\text { - Better survival rates of the implant when Bio-Oss was used as } \\
\text { the only bone graft material } \\
\text { - High long-term survival rates of implants, placed in areas where } \\
\text { Bio-Oss was used. } \\
\text { - Bio-Oss particles connected between each other through bone } \\
\text { bridges coveredby newly formed bone }\end{array}$ \\
\hline $\begin{array}{l}\text { Lee DZ, Chen ST, } \\
\text { Darby IB. (2012) } \\
\text { [28] }\end{array}$ & $\begin{array}{l}\text { Evaluate clinical and histomorphometric } \\
\text { results of maxillary sinus floor lifting using } \\
\text { deproteinized mineral bovine bone graft } \\
\text { (DBBM) }\end{array}$ & $\begin{array}{l}\text { Three years and nine } \\
\text { months. }\end{array}$ & $\begin{array}{l}\text { - } 100 \% \text { Survival and sucess rates of implants after } 3 \text { year avarage } \\
\text { period } \\
\text { - Bone tissue in intimate contact and aligning the surface of bone } \\
\text { graft particles } \\
\text { - Bone grafting with Bio-Oss resulted in six to eight times in bone } \\
\text { height increase. } \\
\text { - Bone at the time of implant placement was of high density and } \\
\text { proper vascularity. }\end{array}$ \\
\hline $\begin{array}{l}\text { Pietro F, Piattelli A, } \\
\text { lezzi G, Degidi M, } \\
\text { Marchetti C.(2010) } \\
\text { [29] }\end{array}$ & $\begin{array}{l}\text { Describe a procedure of increasement } \\
\text { developed to allow a implant supported } \\
\text { prosthetic reabilitation }\end{array}$ & Twelve months. & $\begin{array}{l}\text { The deproteinized mineral bovine bone graft particles have } \\
\text { positive osteoconductive properties } \\
\text { Slow resorption of the graft supporting mechanical stability of } \\
\text { surgical site during apropriate healing period. }\end{array}$ \\
\hline $\begin{array}{c}\text { Todisco M.(2010) } \\
\text { [30] }\end{array}$ & $\begin{array}{l}\text { Evaluate the sucess rate- year after loading } \\
\text { of early loaded implants, placed in vertically } \\
\text { increased bone, using deproteinized } \\
\text { bovine bone graft (Bio-Oss) and a titanium- } \\
\text { reinforced membrane (Gore-Tex) }\end{array}$ & Two years. & $\begin{array}{l}\text { - Its slow resorption may be pointed as a positive finding, } \\
\text { suggesting long term stability of regenerated tissue. } \\
\text { The Bio-Oss particles remained very close to alveolar bone. } \\
\text { Excelente sucess rate with acceptable peri-implant bone loss } \\
\text { after a year of function }\end{array}$ \\
\hline $\begin{array}{l}\text { Mardas N, Chadha V, } \\
\text { Donos N.(2010) } \\
\text { [31] }\end{array}$ & $\begin{array}{l}\text { Compare the potential of a synthetic } \\
\text { bone substitute or a bovine xenograft } \\
\text { combined with a collagen membrane to } \\
\text { preserve alveolar ridge dimensions after } \\
\text { teeth extraction. }\end{array}$ & Eightmonths. & $\begin{array}{l}\text { - Confirmed its osteoconductivity and new bone formation. } \\
\text { - Approved to treat peri-implant defects of deiscency. } \\
\text { - Partially preserved bone width and height of alveolar crest, } \\
\text { allowing implant placement. }\end{array}$ \\
\hline $\begin{array}{l}\text { Pietro F.etal. } \\
\text { (2008) } \\
{[32]}\end{array}$ & $\begin{array}{c}\text { Compare efficacy, complications and } \\
\text { patients preference over two different } \\
\text { techniques of bone height increasementin } \\
\text { posterior mandibular region :bone blocks } \\
\text { harvested from illiac crest versus inorganic } \\
\text { bovine bone blocks (Bio-Oss) usedas } \\
\text { inlays. }\end{array}$ & $\begin{array}{c}\text { Five years and eight } \\
\text { months. }\end{array}$ & $\begin{array}{l}\text { - Using Bio-Oss is preferable than harvesting bone fro illiac crest. } \\
\text { - The sides that undergone vertical height increasement with a } \\
\text { bone substitute recovered sensitiveness faster than the sides } \\
\text { treated with autogenous bone. }\end{array}$ \\
\hline $\begin{array}{l}\text { Cordaro L, } \\
\text { BosshardtDD, } \\
\text { PalattellaP,Rao W, } \\
\text { Serino G, Chiapasco } \\
\text { M.(2008) } \\
\text { [33] }\end{array}$ & $\begin{array}{c}\text { Compare histomorphometric results of } \\
\text { maxillary sinus grafting with anorganic } \\
\text { bovine bone (ABB) and biphasic } \\
\text { calcium phosphate (BCP)(Straumann, } \\
\text { BoneCeramic) }\end{array}$ & Eighteen months. & $\begin{array}{l}\text { - Confirmed its osteoconductive properties. } \\
\text { - Demonstrated that resorption occured very slowly. } \\
\text { - Avoid surgical procedures of autogenous bone harvesting. } \\
\text { - Showed intimate contact between xenograft and newly formed } \\
\text { bone }\end{array}$ \\
\hline $\begin{array}{c}\text { Steigmann M.(2008) } \\
\text { [34] }\end{array}$ & $\begin{array}{l}\text { Report the use of a mineral block of bovine } \\
\text { bone combined with a resorbable collagen } \\
\text { membrane to increasea vertically and } \\
\text { horizontally. }\end{array}$ & $\begin{array}{l}\text { Three years and six } \\
\text { months. }\end{array}$ & $\begin{array}{l}\text { - Due to its slow remodelling process it mantains its volume during } \\
\text { a long period of time. } \\
\text { - Garantees interproximal bone height stability untill implants can } \\
\text { be functionally loaded. } \\
\text { - Suitable for severe deficiencies enhancement. }\end{array}$ \\
\hline $\begin{array}{c}\text { Valentini P, } \\
\text { Abensur D, } \\
\text { Wenz B, } \\
\text { Peetz M, } \\
\text { Schenfe R.(2000) } \\
\text { [35] }\end{array}$ & $\begin{array}{l}\text { Evaluate efficacy of Bio-Oss in } \\
\text { the contexto of a clinical and } \\
\text { histomorphometric study. }\end{array}$ & Two years. & $\begin{array}{l}\text { - Confirms to be a good osteoconductive materialthat leadsto } \\
\text { effective osteointegration of dental implants } \\
\text { - Indicates high level of calcification suggesting an intimate } \\
\text { contact between itself and newly formed bone. } \\
\text { - Indicates a very slow resorption of grafting material. } \\
\text { - Can be sucessfully used in maxillary sinus grafting. }\end{array}$ \\
\hline
\end{tabular}




\section{DISCUSSION}

The reconstruction of bone deformities, by trauma, infection, neoplasies or periodontal disease is one of challenges for the dentist [1]. On the other hand of this statement, the use of bone grafts allows to guide bone regeneration after a surgical procedure.

Bio-Oss is a bone substitute of bovine origin (xenograft), in which all the organic components are extracted, supporting the natural bone architecture. Due to its structure, Bio-Oss is phisically and chemically comparable to mineralized matrix of human boné [12].This material is highly referredin literature owing to its osteoconductive qualities, high biocompatibility, and proficiency related to autogenous bone graft in undergoing slower resorption, serving as a scaffold to bone neoformation during regenerative process $[13,14,10]$.

The histological findings demonstrate that the Bio-Oss particles are connected between each other through bone bridges and covered by newly formed bone tissue[25-27,31]. Thereby, bone graft behaved like a scaffold through which new bone was formed. Consistently to this, the study of VALENTINI, P. et al, 2000, suggests a high level of calcification, which reports to this intimate contact between xenograft and recently formed bone.

Studies demonstrated in histological evaluations that the deproteinized mineral bovine bone particles have positive osteoconductive properties, being reported by the intimate contact between graft material and recently formed boné $[18,19,24-, 27,29,31,33]$.

Acoordingly to Valentini et al. and Milani et al, Bio-Oss osteoconductive properties objectifies the dental implants proper osteointegration.

Its biocampatibility is confirmed by Oliveira et al. and Bassil et al., assuring that it doesn't promote strange body reactions [27, 26].

Was compared the potential of a synthetic bone substitute related to the bovine origin xenograft on preserving bone dimensions. As a result, both grafts preserved all clinical dimensions of the site, giving support to new bone formation, and allowing the placement of dental implants [31].

In respect of Bio-Oss employment, researches report higher survival rates of the implant, when the graft was used isolatedly $[22,36]$,showing predictable long- term clinical results [21].

The slow resorption oh the bovine xenograft, is considered a positive characteristic, suggesting long term stablity of regenerated tissue $[30,35]$.

The slow remodelling process, maintains the volume during a longer period of time, corroborating to the persistance of interproximal bone height in the grafted site untill implants are functionally loaded and natural bone remodelling occurs [34].

Due to its limited biodegradation, the hyphotesis is that Bio-Oss is a prerrogative to bone preservation and long-term implant sucess [19].

Bio-Oss is widely used in maxillary sinus grafting. Accordingly to several studies, patients treated with implants after procedures of maxillary sinus grafting with xenograft, presented a great clinical response, ratifying the assertivity of material usage for grafting procedures in those sites $[19,20,25,26,35]$.

Cordoraro et al. [33] confirmed the advantage of using xenograft (Bio-Oss) because it provides confort to patient and surgeon, in spite of surgery is restrained to the host site, avoiding bone harvesting procedures that are necessary to use autogenous graft.

Accordingly to Schmitt et al. [19], the addition of autogenous bone together with Bio-Oss has no beneficial effect when compared to isolated use of Bio-Oss in the maxillary sinus grafting. Therefore, these authors preach the isolated use of Bio-Oss, because the same avoids the harvesting of autogenous bone, decreasing the possible patient morbidity. 
In spite of the numerous benefits of Bio-Oss already mentioned, it has some disadvantages, such as the time between grafting and its integration into the recipient bed, which can vary from 6 to 10 months, which may stimulate the search for its association with other substances that accelerate the local bone neoformation [37].

Hallman et al. shows in his study that a longer healing period is required for the maxillary sinus grafted only with Bio-Oss because the new bone proliferation occurs only from the peripheral walls of the bone, so the addition of autogenous bone along with Bio-Oss facilitates the proliferation of vessels and tissues; thus, new bone formation and incorporation of the grafts takes less time to heal.

\section{CONCLUSION}

It is concluded that the use of bio-oss as a bone substitute is a viable alternative in the placement before dental implants, being used in clinical practice and with proved efficacy in several studies, due to its similarity with the bone and its high level of osteoconductivity.

\section{REFERENCES}

1. Larsson L, Decker AM, Nibali L, Pilipchuk SP,Berglundh T, Giannobile WV. Regenerative medicine for periodontal and periimplant diseases. J Dent Res. 2016 Mar;95(3):255-66. doi:10.1177/0022034515618887. Epub2015 Nov 25.

2. Baldini N., De Sanctis M., Ferrari M. Deproteinized bovine bone in periodontal and implant surgery. Dent Mater.2011Jan;27(1):61-70. do::10.1016/j. dental.2010.10.017.Epub2010 Nov 27.

3. Crenshaw AH. Técnicas cirúrgicas. In: Crenshaw AH. Cirurgia ortopédica de Campbell. São Paulo:Manole; 1996. p.13-17.

4. Dinato JC, Nunes LS, Smidt R. Técnicas cirúrgicas para regeneração óssea viabilizando a instalação de implantes. In: Saba-Chufji E,Pereira SAS, organizadores. Periodontologia: integração e resultados. São Paulo: Artes Médicas; 2007.p.183-226.

5. Jensen SS, Aaboe M, Pinholt EM, Hjørting-Hansen E, Melsen F, Ruyter IE. Tissue reaction and material characteristics of four bone substitutes. Int J Oral Maxillofac Implants. 1996 Jan-Feb;11(1):55-66.

6. Brunsvold M.A, Mellonig JT. Bone grafts and periodontal regeneration. Periodontol 2000. 1993 Feb; ;1):80-91.

7. Stephan EB, Jiang D, Lynch S, Bush P,Dziak R. Anorganic bovine supports osteoblastic cell attachment and proliferation. J Periodontol. 1999 Apr:70(4):364-9.
8. Gosain AK. Plastic surgery educational foundation data committee. Bioactive glass for bone replacement in craniomaxillofacial reconstruction. Plast Reconstr Surg.2004 Aug;114(2):590-3.

9. De Riu G,Meloni MS, Pisano M, Baj A, Tullio A. Mandibular coronoid process grafting for alveolar ridge defects. Oral Surg Oral Med Oral Pathol Oral Radiol. 2012 Oct;114(4):430-6. doi:10.1016/j.0000.2011.11.031. Epub 2012 Aug 2.

10. Caubet J, Ramis JM, Ramos-Murguialday M, Morey MA, Monjo M. Gene expression and morphometric parameters of human bone biopsies after maxillary sinus floor elevation with autologous bone combined with Bio-0ss or BoneCeramic. Clin Oral Impl Res. 2015;2(1):727-735. doi: 10.1111/clr.12380. Epub 2014 Mar 31.

11. Boss JH, Shajrwa J, Arenullah J, Mendes DG. The relativity of biocompatibility. A critical of the concept of biocompatibility. Israel J Med Sei. 1995;31(4):203-9.

12. Tapety Fl,Amizuka N,Uoshima K,Nomura S, Maeda T. A histological evaluation ofthe involvement of bio-oss in osteoblastic differentiation band matrix synthesis. Clin Oral Impl Res. 2004; 15(1):315-324.

13. Traini T,Valentini P,Lezzi G, Piattelli A. A histologic and histomorphometric evaluationof anorganic bovine bone retrieved 9 years after a sinus augmentation procedure.J Periodontol. 2007;78(1):955-61.

14. Su-Gwan K, Hak-Kyun K, Sung-Chul L. Combined implantation of particulate dentine, plaster of Paris, and a bone xenograft (Bio-Oss) for bone regeneration in rats. J Craniomaxillofac Surg. 20010ct;29(5):282-8.

15. Piattelli M, Favero GA, Scarano A, Orsini G, Piattelli A. Bone reactions to anorganic bovine bone (bio-oss) used in sinus augmentation procedures: a histologic long-term report of 20 cases in humans. Int J Oral Maxillo Impl. 1999;14(1):835-40

16. Schlegel KA, Fichtner G, Mosgau SS, Wiltfang J. Histologic findings in sinus augmentation with autogenous bone chips versus a bovine bone substitute. Int J Oral Maxillofac Implants. 2003 Jan-Feb;18(1):53-8.

17. Degidi M, Artese L, Rubini C,Perrotti V, lezzi G, Piattelli A. Microvessel density in sinus augmentation procedures using anorganic bovine bone and autologous bone:3 months results. ImplantDent. 2007;16(1):317-25.

18. Milani S, Dal Pozzo L, Rasperini G, Sforza C, Dellavia C. Deproteinized bovine bone remodeling pattern in alveolar socket: a clinical immunohistological evaluation. Clin Oral Impl. Res.2016;27(1):295-302

19. SchmittCM, Moest T, Lutz R, Neukam FW, Schlegel KA. Anorganic bovine bone (ABB) vs. autologous bone (AB) plus $A B B$ in maxillary sinus grafting. $A$ prospective nonrandomized clinical and histomorphometrical trial. Clin. Oral Impl Res. 2015;26(1):1043-50.

20. Meloni SM, Jovanovic SA, Lolli FM, Cassisa C, De Riu G, Pisano M etal. Grafting after sinus lift with anorganic bovine bone alonecompared with $50: 50$ anorganic bovine bone and autologousbone: results of a pilot randomised trial at one year. Br J Oral Maxillofac Surg. 2015 May;53(5):436-41. doi: 10.1016/j. bjoms.2015.02.012. Epub2015 Mar 19.

21. LutzR, Fink SB, Stockmann P, Neukam FW, Schlegel KA. Sinus floor augmentation with autogenous bone versus a bovine-derived xenograft -a 5-year retrospective study. Clin. Oral Impl. Res.2015;26(1):644-8.

22. Erdem NF,Ciftçi A, Acar AH. Three-Year Clinical and Radiographic Implant Follow-up in Sinus-Lifted Maxilla With Lateral Window Technique. Implant Dent 2016;25(1):214-21.

23. Pang C, Ding Y, Zhou H, Qin R, Hou R, Zhang G. Alveolar ridge preservation with deproteinized bovine bone graft and collagen membrane and delayed implants. J Craniofac Surg. 2014 Sep;25(5):1698-702. doi: 10.1097/ SCS.0000000000000887.

24. De Lange GL, Overman JR, Farré-GuaschE, Korstjens CM, Hartman B, Langenbach GE etal. A histomorphometric and microecomputed tomography 
study of bone regeneration in the maxillary sinus comparing biphasic calcium phosphate and deproteinized cancellous bovine bone in a human split-mouth model. Oral Surg Oral Med Oral Pathol Oral Radiol. 2014 Jan;117(1):8-22. doi: 10.1016/j.0000.2013.08.008. Epub 20130ct30.

25. Schmitt CM, Doering H, Schmidt T, Lutz R, Neukam FW, Schlegel KA. Histological results after maxillary sinus augmentation with Straumann BoneCeramic, Bio-Oss, Puros, and autologous bone. A randomized controlled clinical trial. Clin Oral Impl Res. 2013;24(1):576-85.

26. Bassil J1, Naaman N, Lattouf R, Kassis C, Changotade S, Baroukh B etal. Clinical, Histological, and Histomorphometrical Analysis of Maxillary Sinus Augmentation Using Inorganic Bovine in Humans: Preliminary Results. J Oral Implantol. 2013 Feb;39(1):73-80. doi: 10.1563/AAID-J0I-D-11-00012. Epub 2011 Sep 9 .

27. Oliveira R, Hage ME, Carrel JP,Lombardi T,Bernard JP.Rehabilitation of the edentulous posterior maxilla after sinus floor elevation using deproteinized bovine bone: A 9-year clinical study. Implant Dent. 2012;21(5):422-6.

28. Lee DZ, Chen ST, Darby IB. Maxillary sinus floor elevation and grafting with deproteinized bovine bone mineral: a clinical and histomorphometric study. Clin Oral Implants Res. 2012 Aug;23(8):918-24. doi: 10.1111/.1600-0501.2011.02239.x. Epub 2011Jun24.

29. Felice P,Piattelli A, lezzi G, Degidi M, Marchetti C. Reconstruction of an atrophied posterior mandible with the inlay technique and inorganic bovine bone block: a case report. Int J Periodontics Restorative Dent.2010 Dec;30(6):583-91.

30. Todisco Marzio. Early loading of implants in vertically augmented bone with non-resorbable membranes and deproteinised anorganic bovine bone. An uncontrolled prospective cohortstudy. Eur J Oral Implantol. 2010;3(1):47-58.
31. Mardas N, Chadha V, Donos N. Alveolar ridge preservation with guided bone regeneration and a synthetic bone substitute or a bovine-derived xenograft: a randomized, controlled clinical trial. Clin. Oral Impl. Res. 2010;20(1);688-98.

32. Felice P,Marchetti C, Piattelli A, Pellegrino G, Checchi V, Worthington H et al. Vertical ridge augmentation of the atrophic posterior mandible with interpositional block grafts: bone from the iliac crest versus bovine anorganic bone. Results up to delivery of the final prostheses from a split-mouth, randomised controlled clinical trial. Eur J Oral Implantol. 2008; (3):183-98

33. Cordaro L, BosshardtDD, PalattellaP,Rao W, Serino G, Chiapasco M. Maxillary sinus grafting with Bio-0sss or Straumanns Bone Ceramic: histomorphometric results from a randomized controlled multicenter clinical trial. Clin Oral Impl.Res.2008;19(1):796-803.

34. Steigmann M. A bovine-bone mineral block for the treatment of severe ridge deficiencies in the anterior region: a clinical case report. Int J Oral Maxillofac Implants. 2008 Jan-Feb;23(1):123-8.

35. Valentini P,Abensur D, Wenz B, Peetz M, Schenfe R. Sinus Grafting with Porous Bone Mineral (Bio-Oss) for Implant Placement: a5-Year Study on 15 Patients. Int JPeriodontics Restorative Dent. 2000 Jun;20(3):245-53.

36. Hallman M, Sennerby L, Lundgren S. A clinical and histologic evaluation of implant integration in the posterior maxilla after sinus oor augmentation with autogenous bone, bovine hydroxyapatite, or a 20:80 mixture. Int J Oral Maxillofac Implants. 2002;17:635-43.

37. Wallace SS, Froum SJ, Cho SC, Elian N, Monteiro D, Kim BS, Tarnow DP. Sinus augmentation utilizing anorganic bovine bone (Bio-Oss) with absorbable and nonabsorbable membranes placed over the lateral window: histomorphometric and clinical analyses. Int J Periodontics Restorative Dent. 2005 Dec;25(6):551-9.

\section{Jhenifer Rodrigues Silva}

(Corresponding address)

Instituto de Ciência e Tecnologia - ICT / Unesp

Av. Dr. Eng.Francisco Jose Longo, 777, Jd. Sao Dimas

Sao Jose dos Campos, Brazil

Date submitted: 2018 Nov 07

Email: jhenifer.silva@ict.unesp.br 